\title{
Children in Brick Kiln: Scenario in Odisha
}

\author{
Ranjan Kumar Mohanty ${ }^{1}$ and Sushree Shailani Suman ${ }^{2^{*}}$ \\ ${ }^{1}$ Secretary-cum-Chief Executive, People's Cultural Centre, PECUC, Bhubaneswar-751020, Odisha, India \\ ${ }^{2}$ Chief Editor, Research, PECUC, Bhubaneswar-751020, Odisha, India \\ *Corresponding author: sushree_suman@hotmail.com
}

Received: 14-01-2020

Revised: 19-04-2020

Accepted: 25-05-2020

\begin{abstract}
The current review focuses on the children who are engaged in labor, especially brick kiln industries that has not only affected them but the environment as a whole. The major study area is Odisha, an eastern state in India that shows high incidence of children being employed in such places. This article also focuses on various laws and legislations associated with this scenario along with certain recommendations that will be presented to the policy makers and the key stakeholders.
\end{abstract}

Keywords: Children, child labor, Odisha

Approximately, 1.5 billion bricks are produced annually on a global basis. Among these, the traditional brick kiln units are the highest contributors to the Asian brick markets. The brick kiln production technologies in South Asia mainly involves traditional firing and hand molding technologies, and fully mechanized and automated brick kilns are least found in these countries. However, the developed countries implement advanced technological processes like natural gas fired tunnels (USA/Europe), and the Tunnel and Hoffman kilns of China, which are considered environment friendly technologies (Kamyotra, 2015).

In South Asian scenario, most of these brick kilns are informally organized, which is making it difficult to obtain real data dealing with the numbers of brick kilns, labor (women, men and children) and animal being used in the process of brick making and its impact on environment. This informal nature has also made the monitoring and regulation a difficult task.

The present study is first in its kind that puts a spotlight on the invisibility of the brick making industry in India. The study aims at:

1. Providing a comprehensive picture of the existing brick kiln industries,

2. Overall impact of brick kiln industries on humans, animals and environment,

3. It also presents the future recommendations for policy makers with clear cut solution-oriented actions.

\section{Brick kiln in India}

After China, India is the second largest brick producer in the world $(1,40,000$ brick units) with an annual growth of $5-10 \%$. The brick kilns that feed the booming construction sector of India are a crucial part of India's growing economy that contributes around 300 billion rupees to the country's economy every year. According to the Punjab state council for science and technology, there are around 1, 25,000 kilns in the country. The Gangetic plain of North India accounts for about $65 \%$ of 
the total brick production (Development Alternatives, 2012). However, the profitability of brick industries is higher in southern India compared to north making it more vulnerable. This is due to the higher selling price of bricks (Bisht and Neupane, 2015). In Indian scenario, coal and biomass are the main source fuels for such industries. The sector consumes around 3540 million tons of coal per year, making it the third largest coal consumer in the world. The expense on fuel accounts for half of the total cost of brick making (The Wire, 2016) making it equally competitive with other sectors for acquiring the resource share, which in turn possesses a significant energy challenge as coal is also one of the crucial resource in power and steel sectors. Punjab, Haryana, Uttar Pradesh, Bihar, West Bengal and Odisha are the major brick producing states of India. In southern India, apart from coal, firewood is also considered a major fuel source; however, its cost is also increasing leaps and bounds. States like Andhra Pradesh and Odisha have seen exacerbation of brick kilns due to cheap availability of source fuel, water and soil. Hence, most of these industries flourish near the river banks of all major rivers of these states (Orion et al., 2011). Annual brick production in India accounts to 240-260 billion, which in turn emits 66 million $\mathrm{t}$ of $\mathrm{CO}_{2}$ with consumption of 500 million $\mathrm{m}^{3}$ clay (Kamyotra, 2015; Ecobricks, n.d.).

In addition, $99 \%$ of brick production is done through traditional method of hand molding; $74 \%$ of production is done through Bull's Trench Kilns (BTKs) and 21\% through Clamp kilns (Kamyotra, 2015). In numbers, there are around 33,000 BTKs and 2000 clamp/down draft, high draft and zigzag kilns (The Wire, 2016).

\section{Environment assessment of brick kiln industries}

The brick kiln industries have posed extensive damage to the environment, both short term and long term, in small scale sector (Orion et al. 2011). These industries have not only polluted the atmosphere, but also the nearby water bodies and soil of that particular area.

\section{Reducing forest area}

The states using firewood as fuel source accounts for 25$26 \%$, which in turns causes deforestation. Such rampant cutting down of trees has put many tree species like keora, 'chaila', sundari, mehgini, bain under threat (NSSO, 2011).

\section{Air Pollution and its Emission Sources}

The emission sources are categorized into stack emission and fugitive emission. The former occurs during the brick making process in form of thick smoke in kilns (especially in kilns with shorter combustion zones), whereas the latter occurs due to various reasons, such as during fuel charging, clay excavation, removing dust from brick settings, during high winds, loading of bricks, coal crushing, cleaning trench bottom, and so on.

As mentioned earlier, 66 million tons of $\mathrm{CO}_{2}$ is released from the brick industries every year. As the industry consumes a larger chunk of coal every year, in addition to $\mathrm{CO}_{2}$, it also releases many toxic air pollutants like suspended particulate matter (SPM), carbon monoxide, sulphur dioxide $\left(\mathrm{SO}_{2}\right)$, and nitrogen oxides (NOx). The increased carbon dioxide concentration also leads to regional and global warming. The large amounts of coal used for brick firing also leave behind bottom ash as residue. The air pollution and bottom ash generated cause considerable health problems, especially related to respiratory health, while also causing damage to property and crops. Surprisingly, in a primary study conducted in Odisha, it has been observed that $83 \%$ brick kiln owners did not obtain any pollution clearance certificates (Orion et al. 2011).

\section{Land Pollution}

The brick kiln industries results in land degradation, which refers to degradation of the land quality along with its productivity, making it unfit for agriculture. Most of these industries are situated on river banks due to availability of clay, silt, and alluvial soil types that has the suited texture for brick making. Excavating the top soil from these areas leaves the land infertile (Datta et al. 1996). The fast depletion of cultivable land also raises concern for the country's food security.

\section{Water Pollution}

Due to excessive and in-depth excavation, brick kiln industries have shown to affect the ground water 
quality resulting out of leaching. The seepage from the brick kiln industries to nearby water bodies pollutes the water by discharging different types of solids, reducing the dissolved oxygen content, increasing calcium and total hardness of the water (Extremology, 2013). The deterioration in the water quality has affected the aquatic balance as well the aquatic animal's lives to a greater extent.

The Supreme Court of India issued a directive for discontinuing the movable chimney kilns and for all brick kilns to conform to new environmental norms. But such kilns continue to function and flout environmental regulations due to lax monitoring mechanisms (Ecobricks, n.d.).

\section{Assessment of Human Labors in Brick Kilns}

The brick kiln industry in India is a labor-intensive sector that flourishes mostly on manual labor, including men, women and children, as well as animals like donkeys. The industry is vulnerable to bonded and forced labor.

\section{Migration into Bondage and Forced Labor}

The 2011-12 NSSO survey report stated that of the total workforce of 472.9 million, 23 million (5\%) of the workers are employed in brick kiln. Most of the workers are migrants from states with poor economic profile, and they predominantly belongs to discriminated groups of the society, including the scheduled castes, scheduled tribes, religious minority groups as well as indigenous people. According to the ILO's Forced Labor Convention, "forced or compulsory labor is all work or service which is exacted from any person under the threat of a penalty and for which the person has not offered himself or herself voluntarily. It can occur where work is forced upon people by State authorities, by private enterprises or by individuals." The bonded or forced labors are usually landless, who are usually trapped in debt bondage as they do not have any alternative livelihood source. The bonded labors are also not paid a regular monthly wages and payments are made on the basis of brick production. The working hours are even strenuous and 8 hours a day schedule is not implemented by most of the owners, thus dragging them towards slavery. This slavery system continues till generation till the repay of the debt, making the situation of the family members even more vulnerable (Menon, 2014). The Bonded Labour System (Abolition) (BLSA) Act of 1976 was promulgated in India to protect the worker's interest from debt bondage. All the brick kilns of India are covered under the Minimum Wages Act of 1948. However, implementation of the Act has been ineffective.

\section{Invisible Women Workers of the Brick Kiln Industry}

Approximately half of the brick kiln worker populations are women (approximately 120 million); however, their contribution is least recognized (NSSO, 2011). Neither are they given equal wages as their male counterpart nor any such medical facilities. Most of the women working in brick industries face sexual exploitation and violence, though very few studies have been done in this context. They are usually forced to work even during illness, pregnancy, and by carrying their children, which in turn exposes the children to various health hazards. Many of these female workers work at such vulnerable and stressful conditions to repay the debts created by the husband or father (Development Alternatives, 2012).

\section{Focusing on Child Labor in Brick Kiln Industries}

The Child Labour (Prohibition and Prevention) Amendment Act, 2016 prohibits adolescents under 18 years of age to work in any of the hazardous sectors (hazardous process, mining and explosive industries) and prohibits engagement of children under 14 years in all occupations. This has made the children between the age group of 14-18 years, more vulnerable. However, there are many flaws associated with the law as t outlaws many sectors like brick kilns, chemical units, cotton farms and so on, from the hazardous list. In contrast, the International Law prohibits engagement of children below 18 years to work in any of the worst forms of child labor (bonded and forced labor), which is likely to have negative impact on the child's mental, physical and social well-being. Hence, brick kiln industries can be considered as one of the prohibited occupations.

\section{Reasons for engaging child labor}

Children have always been the cheapest labor source 
for all sectors employing them. Of the total workforce in brick industries, $20 \%$ are children. Poverty is considered to be one of the foremost reasons of child labor. Low parental income compels the children to move out of the schools and engage in bonded or forced labor like that of brick kiln industries. There are also certain families that believe that if the children will work when young, they can earn in leaps and bounds when they are adults. This is the aftermath of illiteracy and lack of awareness. In case of families working in brick kiln set-ups, also take their young children to the work site, which again raises health concerns in infants as well as young children who are exposed to these hazardous environmental conditions (Extremology, 2013; Ecobricks, n.d.).

\section{Migration and Child Labor}

Children migrate to the brick kiln sites either alone or with families. They can even migrate with their parents or relatives to take care of their siblings. At times, they migrate with their parents, as there is no one in their home to take care of them. Nearly, 3 lakh children work in brick manufacturing, of which 84,972 work only in brick kilns. The invisibility of such migrant children results in their exclusion from linkage with development programs. The largest number of child workers, i.e. 122 million constituting $64 \%$ is mainly concentrated in Asia and the Pacific, of which India accounts for a substantial size (Das, 2015). The major migrating source states Odisha, Chhattisgarh, Jharkhand, Bihar, UP, West Bengal and Andhra Pradesh. The migration duration is usually 6-8 months in case of brick manufacturing industries. Seventeen percent of children between the age group 0-3 years are migrants. Likewise, $81 \%$ between the age group 0-6 years, $80 \%$ between the age group 6-14 years, and $83 \%$ between the age group 1418 years are migrants. Only $0.18 \%$ crèche facilities are available at the destination. The children involved in migration, usually discontinue schools that results in high dropout (Pufall et al. 2015).

\section{Working Conditions and Health Hazards at Brick Kilns}

In the functional brick kiln areas, the access to primary health services remains low. If they fall ill, returning to their homes is the only way out. Work-related diseases are very common among the workers, children being the easiest prey. A study stated that out of 6000 workers examined, the most prevalent diseases were anemia, arthritis, burns, cardiac problem, body ache, ear problem, eye problem, Eczema, Jaundice, Migraine, menopause, silicosis, asbestosis and pneumoconiosis and so on. They are also exposed to the high levels of suspended particulate matter as the furnace chamber is covered with ash or during manual coal breaking that leads to pulmonary diseases and asthma. The brick kiln workers are at higher risk of occupational health hazards due to the seasonal nature of brick kiln functioning (Ecobricks, n.d.). Many children, especially girls, are subjected to sexual abuse and harassment at the workplace as well (Das, 2015). Most of the brick manufacturing units do not have any work regulation. They do not provide any safety or protective equipment like face masks. The working hours often exceeds more than 9-10 hours a day and again seven days a week (Chanda, 2016).

\section{Living Conditions at Brick Kilns}

The brick kiln workers live in extremely unhygienic conditions without proper sanitation, water supply and electricity connection (Development alternatives, 2012). The brick kiln workers usually resides at the place of work by building temporary or kuccha huts. In general, these houses are overcrowded, which can again increase the risk of spreading infectious diseases. They do not even get proper nutrition due to irregular diets or distorted food behavior. Open defecation is also prevalent among the workers due to lack of sanitary facilities (Chanda, 2016).

\section{Interventions of Trade Unions, State and NGOs/ CSOs}

The trade unions enable brick kiln workers to unionize to demand their needed rights, like advocating for minimum wage and provision for provident fund. The union can promote child labor free zones and manage schools at the site. Union and state can zero down on treaties to stop engagement of child labors in the brick manufacturing units. Taking a step further, the state can intervene in setting up of welfare board for the 
workers at brick kiln industries. The district level task force can play as a great instrument in implementing various legal actions, conducting raids, rescue as well as rehabilitation. The facility of seasonal hostels to be provided for the children of the workers. The workers who migrate to the brick kiln site for work should be registered at panchayats. However, the NGOs too have a crucial role to play at the source, transit and destination of migrating workers. The organizations can enroll the children at the site into bridge course programs through informal schooling. They need to channelize the linkage of workers with poverty alleviation programs so they can reap the benefits for better sustenance. Living condition is a greater concern for the workers at brick kiln units. Hence, transit homes needs to be set up at nearby locations. The pregnant woman needs to be registered at nearby anganwadi centers or ICDS. NGOs should spread awareness regarding safe migration and different policies for children, men and women at their field of work from where most of the migration is taking place.

\section{Laws and Legislations}

Only 33\% of brick kiln owners have registered at district industrial center (DIC) till date (Orion et al. 2011). Taking into consideration the climatic scenario, a notification was released by the GOI in the year 1996, which aimed at setting up emission standards for brick kiln industries (Gazette Notification G.S.R.543(E) dated 22nd July 2009). A part from this, the Ministry of Environment and Forests has also set up certain guidelines for the brick kiln units to follow. Some of them are ineligibility of brick kilns to convert forest lands for non-forest activities (Forest Conservation Act, 1980), or convert agriculture fields into industrial sites, and so on. There is a provision of obtaining a clearance from Central/State Pollution Control Boards before setting up a unit. The permission is obtained in form of No Objection Certificate (NOC) that needs to be renewed annually. The NOC aims at checking the air, soil and water pollution by providing stringent regulatory norms. Another notification S.0.763 (E) was published in 1999 that restricts excavation of top soil for brick making; hence, promoting use of fly ash in brick manufacturing (Ecobricks World, 2014).
Regarding the use of fuel, use of firewood has been prohibited by the brick burning control ordinance of 1992. The Brick Kiln Control (amended) Act (2001) prohibits setting up of brick kiln units within a 3-km radius of human settlement or fruit gardens (Orion et al., 2011). India is also a participant in the second ILO Decent Work Country Programme (2013-2017). A joint project was initiated between the ILO and the Ministry of Labour and Employment to reduce vulnerability to bonded labor through the promotion of decent work is implemented in the brick kiln sector in select districts of Odisha, Andhra Pradesh, Uttar Pradesh, Chhattisgarh, Jharkhand and Bihar. The Interstate Migrant Workman Act of 1979, which is particularly relevant to the situation of brick kiln workers given that the majority are interstate migrants, has failed to regulate and facilitate safe and protected migration. The Act has yet to see the development of a system to register labor contractors and laborers, who are recruited at the source area (Antislavery, 2015).

\section{Recommendations}

1. Promotion of deep mining of clay instead of surface mining.

2. Promoting use of fly ash in brick making.

3. Instead of solid brick making, perforated/hollow bricks production needs to be promoted that will lead to reduced material use. Hollow brick making also consumes less energy and pollutes less.

4. Promotion of ecofriendly brick production technologies through capacity building of policy makers for creation of an enabling environment for implementation of such technologies.

5. There should be review of existing policies and formulation of new policies related to energyresource efficient brick production.

6. There is a need for amending the draft wages code for ensuring strict working age and work hours.

7. Free vocational training or informal education should be made available to the children, who have migrated to the working site with their parents.

8. There is a need for spreading awareness on the effects of child labor, the various rights of 
the children and working adults, and working hazards through a partnered approach of various stakeholders like NGOs, govt., panchayats, parents and children.

9. Work safety guidelines should be standardized for all brick kiln units throughout the country. The employer should be responsible for providing safety equipment to the workers.

10. Civil societies should also be made aware through different awareness programs for enhancing cleaner brick use.

11. As there are very few studies on the present status of the brick kiln industries, there is a need for a nationwide statistical survey on the present scenario of brick kiln workers (especially children and women who work as disguised employees).

12. The Integrated Child Development Services officials and Labor Officials should inspect all brick kilns on a regular basis to ensure Anganwadi services are provided and that children are able to attend schools in accordance with the Right to Education Act 2006.

13. Financial institutions should be sensitized to support financial needs of credit worthy brick kiln entrepreneurs.

14. Minimum hygienic living standard should be provided to the workers and their family along with safe drinking water and proper sanitation facilities.

\section{REFERENCES}

1. Kamyotra, J.S. 2015. Brick Kilns in India. June 2015.

2. Development Alternatives. 2012. Status of Brick Sector in the State of Bihar - A baseline study. 43 p. Development Alternatives, New Delhi, India.

3. Bisht, G. and S. Neupane. 2015. Impact of Brick Kilns' Emission on Soil Quality of Agriculture Fields in the Vicinity of Selected Bhaktapur Area of Nepal. Applied and Environmental Soil Science, Vol. 8.

4. The Wire. 2016. Controversy Over How Indian Brick Kilns Clean up Their Act. Disponible en https://thewire.in/44503/ controversy-over-how-indian-brick-kilns-clean-up-their-act/
5. Orion, Vijay, D.M., Menon, P.A. et al. 2011. Environmental pollution from brick making operations and their effect on workers. Disponible en https://businessimpactenvironment. wordpress.com/2011/10/03/environmental-pollution-frombrick-making-operations-and-their-effect-on-workers/

6. Ecobricks. (n.d.). Issues in the Indian Brick Sector. Disponible en http://www.ecobrick.in/challenges_Issues_in_the_Indian_ Brick_Sector.aspx

7. NSSO. 2011. Census report. Disponible en https://censusindia. gov.in/

8. Datta, P.S., Deb, D.L. and Tyagi, S.K. 1996. Stable isotope (18O) investigations on the processes controlling fluoride contamination of groundwater. Journal of Contaminant Hydrology, 24: 85-96.

9. Extremology. 2013. Important reasons of Child Labor: An analysis to save poor children. Disponible en http://www. extremology.com/2013/02/Important-reasons-of-child-laborwith-analysis.html

10. Menon, S. 2014. Brick Kiln Workers in India: Migrating into Bondage. Labour File, 9: 08.

11. Das, R. 2015. Causes and consequences of child workers in the brick fields of Khejiru CD blocks in Purba Medinipur district, West Bengal. International Journal of Humanities $\mathcal{E}$ Social Sciences, 4: 28-42.

12. Pufall, E.L., Nyamukapa, C., Robertson, L. et al. 2015. Migration as a risk factor for school dropout amongst children made vulnerable by HIV/AIDS: a prospective study in eastern Zimbabwe. Vulnerable Child Youth Studies, 10: 179191.

13. Chanda, D. 2016. A Study on Socio Demographic \& Health Condition of Brick Field Workers in Different Areas of Bangladesh. Dissertation. East West University, Bangladesh.

14. Development alternatives. 2012. The Odisha Brick Sector - A baseline study. Disponible en http://www.ecobrick.in/ resource_data/KBAS100125.pdf

15. Ecobrick World. 2014. Resource Efficiency in Brick Production. Disponible en http://www.ecobrick.in/resource_data/KBAS 100139.pdf

16. Anti-slavery. 2015. Forced labour in the brick kiln sector in India. Disponible en http://www.antislavery.org/wp-content/ uploads/2017/01/forced-labour-in-brick-kilns-in-indiaaugust-2015-briefing.pdf 